\title{
Interactions between mineral fertilization and arbuscular mycorrhizal fungi improve nursery growth and drought tolerance of Prosopis alba seedlings
}

\author{
Carla S. Salto • Mónica B. Sagadin • Celina M. Luna • Gustavo Pedro Javier Oberschelp • \\ Leonel Harrand • Marta N. Cabello
}

Received: 25 April 2018/ Accepted: 16 February 2019

(C) Springer Nature B.V. 2019

\begin{abstract}
Prosopis alba Griseb. (algarrobo blanco) is an important tree legume in semiarid regions of South America. Under field conditions, their seedlings are subjected to a wide range of environmental conditions that might produce stress, reducing their survival and/or growth. The aim of this work was to evaluate the combined effect of two native arbuscular mycorrhizal fungi (AMF) inocula and fertilization on growth variables of $P$. alba seedlings under nursery conditions and after drought stress. $P$. alba seedlings received different levels of basic fertilization $(0 \%$,
\end{abstract}

C. S. Salto $(\bowtie) \cdot$ G. P. J. Oberschelp · L. Harrand Estación Experimental Agropecuaria Concordia, Instituto Nacional de Tecnología Agropecuaria (INTA), Casilla de Correo 34, CP 3200 Concordia, Entre Ríos, Argentina e-mail: salto.carla@inta.gob.ar

M. B. Sagadin · C. M. Luna

Instituto de Fisiología y Recursos Genéticos Vegetales, Centro de Investigaciones Agropecuarias (CIAP) - INTA, Camino 60 Cuadras km 5 1⁄2, CP 5119 Córdoba, Argentina

C. M. Luna

Consejo de Investigaciones Científicas y Técnicas de la República Argentina (CONICET), Córdoba, Argentina

M. N. Cabello

Facultad de Ciencias Naturales y Museo, Instituto de Botánica Carlos Spegazzini, Universidad Nacional de La Plata (FCNyM, UNLP), 53\#477, La Plata, Argentina

M. N. Cabello

Comisión de Investigaciones Científicas de la Provincia de Buenos Aires (CICPBA), Buenos Aires, Argentina
$25 \%$ and $100 \%$ ) and were inoculated with native AMF isolated from different rainfall regions of Parque Chaqueño Argentino: Colonia Benítez (CB, 1300 mm rainfall) and Padre Lozano (PL, $650 \mathrm{~mm}$ rainfall) or a mixture of both inocula (MIX), while the control group remained uninoculated. The combined application of native AMF and fertilization did not affect mycorrhizal colonization but allowed the formation of the different AMF structures. Moreover, when comparing the PL inoculum from a low rainfall region with other treatments, it significantly increased growth and development under nursery conditions and drought stress tolerance in the greenhouse. Therefore, AMF benefits for $P$. alba were related to inoculum source, being improved by the application of low fertilizer rates. This work supports the development of sustainable $P$. alba seedlings production and their field establishment under symbiotic conditions with native AMF.

Keywords "Algarrobo blanco" - Mineral nutrition . Mycorrhizae $\cdot$ Nursery $\cdot$ Water stress

\section{Introduction}

Prosopis alba Griseb. (locally known as algarrobo blanco) is mainly distributed in the central-northern region of Argentina, where it is considered an important forest resource and one of the most valuable 
native tree species due to its multiple uses, providing a wide array of products. Because of that, $P$. alba has been overexploited, leading to native forest degradation. Therefore, field establishment of seedlings, either for commercial purposes and/or restoration of degraded areas, is of utmost relevance (Salto et al. 2017). Under these conditions Prosopis seedlings are exposed to a wide range of environmental conditions that might produce water stress, reducing their survival and/or growth (Villagra et al. 2010).

Good quality seedlings are necessary to ensure establishment and appropriate development of planted forests (Salifu and Jacobs 2006). Nursery plants require adequate quantities of nutrients from the growing medium for basic physiological processes and to promote growth and development. In general, this aspect is addressed in the nursery via fertilization, hardening, and inoculation with mutualistic microorganisms, such as mycorrhizal fungi and/or rhizobia (Jacobs and Landis 2009).

Arbuscular mycorrhizal fungi (AMF) are soil microorganisms that establish symbiotic relationships with plants, being an adaptive strategy to promote growth and survival, to increase nutrient uptake, to reduce fertilizer input requirement, to improve hydric relationships and tolerance to different types of biotic and abiotic stresses (Asmelash et al. 2016). Particularly, AM symbiosis protects host plants against detrimental effect of drought stress through mechanisms of drought avoidance, maintaining an adequate hydration status on the level of whole plants, as well as mechanisms of drought tolerance, related with osmotic adjustment potential and antioxidant metabolism regulation (Rapparini and Peñuelas 2014). All these benefits point out the potential of AMF for commercial application in containerized seedling production (Biermann and Linderman 1983).

Resprouting is considered a key plant functional trait, related to the ability of some plants to form new shoots and increase survival capacity after destruction of living tissues, and many woody species have evolved resprouting strategies to ensure rapid recovery. Therefore, the assessment of this trait, after stress induction, can be considered as reliable indicator of stress tolerance (Zeppel et al. 2015; Pausas et al. 2016). Although AMF may improve water acquisition of host plants, affecting how trees respond to drought stress (Rapparini and Peñuelas 2014), there is so far no mentioning if AMF affects resprouting ability.
Fertilization is one of the most relevant practices for large-scale seedlings production in containers, since an adequate nutrient supply through fertilization can reduce seedling production time and improve seedling quality and growth (Jacobs and Landis 2009). However, fertilization produces changes in the composition and development of AMF (Liu et al. 2012). Moreover, the use of mycorrhizal fungi in nurseries would imply modifying fertilization and watering regimes to support mycorrhizal associations (Wilkinson 2009).

Recently, special interest has been placed on the characterization of native AMF species, as they are considered more adapted to certain environment conditions. The range of plant responsiveness to AM colonization, it varied according to the origin of the AM fungus and associated microorganisms. Knowledge about the characteristics and particular effectiveness of indigenous AM isolates involved in stress tolerance and adaptation under a range of stress conditions is of great interest regarding the possible use of microbial inoculation for reforest practices (Klironomos 2003; Marulanda et al. 2006).

Consequently, the role of AMF and mineral fertilization, and the interaction among them on the growth of $P$. alba seedling needs to be assessed to ultimately optimize the resources used in seedling production. Moreover, such knowledge is of great economic and ecological potential in order to contribute to its silviculture and conservation value (Salto et al. 2017).

The aims of this work were: (1) to evaluate the effect of two native AMF inocula and fertilization on growth variables of $P$. alba seedlings under nursery conditions, and (2) to evaluate resprouting capacity of AMF- $P$. alba seedlings after a drought stress in greenhouse conditions.

\section{Materials and methods}

Isolation and multiplication of AMF inocula

Mixed inocula of native AMF were selected from $P$. alba stands located in Parque Chaqueño Argentino, with two different rainfall regimes: Colonia Benítez (CB) in the Eastern Chaco Domain, Chaco province $\left(27^{\circ} 20^{\prime} 00^{\prime \prime} \mathrm{S}, 58^{\circ} 55^{\prime} 60^{\prime \prime} \mathrm{W}\right)$, with an annual precipitation of $1300 \mathrm{~mm}$, and Padre Lozano (PL) in the 
Western Chaco Domain, Salta province $\left(23^{\circ} 12^{\prime} 51^{\prime \prime} \mathrm{S}\right.$, $63^{\circ} 50^{\prime} 39^{\prime \prime} \mathrm{W}$ ), with $650 \mathrm{~mm}$ annual precipitation.

Soil samples were collected at $0-20 \mathrm{~cm}$ depth under five Prosopis trees from sites separated by approximately $50 \mathrm{~m}$ from each other. Finally, six subsamples from each tree were pooled and mixed and kept at $4{ }^{\circ} \mathrm{C}$ until use. Isolation of AMF species was done by plant traps of Medicago sativa, Sorghum bicolor and P. alba. All seeds were disinfected in $1 \%$ (v/v) sodium hypochlorite for $5 \mathrm{~min}$, and immersed in distilled water for $24 \mathrm{~h}$ at normal temperature. Sterilization of soil, sand, vermiculite, perlite for substrate consisted in subjecting it to a stream of steam at $120{ }^{\circ} \mathrm{C}$ for $2 \mathrm{~h}$, allowed to stand for $24 \mathrm{~h}$ and then repeated once. Then, the seeds were sown in 5-L pots filled with a mix of sterilized soil, sand, vermiculite, perlite $(1: 1: 1: 1 \mathrm{v} / \mathrm{v})$ and $250 \mathrm{~g}$ of unsterilized native soil samples from Colonia Benítez and Padre Lozano regions. For each tree, of the two sites sampled, 15 pots were used, 5 pots with 6 plants per pot of each species used as trap plant. Plants were grown in a greenhouse with $16 \mathrm{~h}$-photoperiod $\left(400 \mu \mathrm{mol} \mathrm{m}{ }^{-2}\right.$ $\mathrm{s}^{-1}$ ) and at $27 \pm 2{ }^{\circ} \mathrm{C}$ and were irrigated with filtered water to avoid the chlorine content and fertilized according (Cabello 1997). Plant roots traps were evaluated after 1 year of growing in a glasshouse (Velazquez and Cabello 2011), percentage of mycorrhizae was measured according to McGonigle et al. (1990). In order to spreading, the roots of the mycorrhized trap plants were mixed with sterilized soil and sand in a 3:1:1 ratio $(\mathrm{v} / \mathrm{v})$ and were placed in 10-L pots containing $P$. alba seedlings, sorghum $(S$. bicolor) and alfalfa ( $M$. sativa) seeds. Trap plants were grown in a greenhouse with $16 \mathrm{~h}$-photoperiod $\left(400 \mu \mathrm{mol} \mathrm{m} \mathrm{m}^{-2} \mathrm{~s}^{-1}\right)$ and at $27 \pm 2{ }^{\circ} \mathrm{C}$ and were irrigated with filtered water to avoid the chlorine content, during 1 year. The AMF inocula was used when mycorrhizal colonization in plant roots was at least 50\% (Sieverding 1991).

Spores of AMF mixture from Padre Lozano (PL) were identified morpho-taxonomically as Claroideoglomus claroideum (N.C. Schenck and G.S. Sm.) C. Walker and A. Schüßler; Claroideoglomus etunicatum (W.N. Becker and Gerd.) C. Walker and A. Schüßler; Diversispora spurca (C.M. Pfeiff., C. Walker and Bloss) C. Walker and A. Schüßler; Funneliformis mosseae (T.H. Nicolson and Gerd.) C. Walker and A. Schüßler and Rhizophagus intraradices (N.C. Schenck and G.S. Sm.) C. Walker and A.
Schüßler. Spores of AMF mixture from Colonia Benítez (CB) were identified morpho-taxonomically as Claroideoglomus claroideum, Claroideoglomus etunicatum, Funneliformis constrictum (Trappe) C. Walker and A. Schüßler; Funneliformis mosseae, Rhizophagus clarus (T.H. Nicolson and N.C. Schenck) C. Walker and A. Schüßler (Sagadin et al. 2018).

Nursery assay

The assay was performed at the forest nursery of the Concordia Agricultural Experimental Station belonging to the National Institute of Agricultural Technology, INTA, located in Concordia city $\left(31^{\circ} 22^{\prime} \mathrm{S}\right.$ and $58^{\circ} 07^{\prime} \mathrm{W} ; 47 \mathrm{~m}$ a.s.l.), Entre Ríos province, Argentina. The region has a temperate-warm climate without dry season, with a mean annual temperature of $18.7^{\circ} \mathrm{C}$ and mean annual precipitation of $1345 \mathrm{~mm}$. $P$. alba seeds were collected from trees from $\mathrm{La} \mathrm{Paz}$ (850-1000 mm rainfall), Entre Ríos $\left(30^{\circ} 56^{\prime} 25^{\prime \prime} \mathrm{S}\right.$, $\left.59^{\circ} 36^{\prime} 18^{\prime \prime} \mathrm{W}\right)$. Pre-germination treatment steps included seed mechanical scarification with sand, immersion in $100{ }^{\circ} \mathrm{C}$ water and finally cooling at air temperature and maintaining in water for $24 \mathrm{~h}$. Seeds were sown in $125 \mathrm{~cm}^{3}$ plastic containers (R125, Dassplastic del Mercosur $\left.{ }^{\circledR}\right)$, using a mixture $(2: 1: 1$ $\mathrm{v} / \mathrm{v})$ of composted pine bark, perlite $\left(\right.$ Perlome $^{\circledR}$ Grueso) and vermiculite (Intersum ${ }^{\circledR}$ Mediano F1), without sterilization as usually used in forestry nurseries. Inoculation was performed at sowing by applying $20 \mathrm{~g}$ of AMF inoculum (a mixture of sterilized substrate, spores, mycelium and fragments of mycorrhizal roots of trap plants) in the planting hole per container for PL, CB and a mixture of similar amounts of both inocula (MIX), control treatment was not inoculated (NI).

Fertilization treatments were based on nutrient solution for fertigation during containerized seedlings production of $P$. alba used by Salto et al. (2016), being full fertilization (100\%); low-input fertilization (25\%), consisted of diluting the $100 \%$ nutrient solution to $25 \%$ (v/v) (Table 1) and non-fertilized control treatment $(0 \%)$. The formulations of nutrient solutions are detailed in Salto et al. (2017). Fertilization treatments began 30 days after sowing during growth phase. Hardening phase, which consists in a controlled stage of stress (full sun, low amounts of available nutrients and limited soil moisture) to acclimate plants 
Table 1 Macro- and micronutrient concentration $\left(\mathrm{mg} \mathrm{L}^{-1}\right)$ for each fertilization solution

\begin{tabular}{lccc}
\hline Nutrient & \multicolumn{2}{c}{ Growth (30-80 days) } & $\begin{array}{l}\text { Hardening } \\
(81-120 \text { days })\end{array}$ \\
\cline { 2 - 3 } & $\begin{array}{lccc}100 \% \\
\mathrm{mg} \mathrm{L}^{-1}\end{array}$ & $\begin{array}{l}25 \% \\
\mathrm{mg} \mathrm{L}^{-1}\end{array}$ & $\begin{array}{l}\text { All treatments } \\
\mathrm{mg} \mathrm{L}^{-1}\end{array}$ \\
\hline $\mathrm{N}$ & 302.70 & 75.70 & 21.00 \\
$\mathrm{P}$ & 72.20 & 18.00 & 16.20 \\
$\mathrm{~K}$ & 158.00 & 39.50 & 186.60 \\
$\mathrm{Ca}$ & 133.00 & 33.30 & 0.00 \\
$\mathrm{Mg}$ & 42.80 & 10.70 & 70.80 \\
$\mathrm{~S}$ & 115.00 & 28.80 & 104.00 \\
$\mathrm{~B}$ & 0.45 & 0.10 & 1.30 \\
$\mathrm{Cu}$ & 0.19 & 0.05 & 0.06 \\
$\mathrm{Fe}$ & 3.50 & 0.90 & 3.20 \\
$\mathrm{Mn}$ & 0.50 & 0.10 & 0.20 \\
$\mathrm{Mo}$ & 0.01 & 0.003 & 0.003 \\
$\mathrm{Zn}$ & 0.19 & 0.05 & 0.10 \\
\hline
\end{tabular}

to outplanting and field establishment (Jacobs and Landis 2009), was initiated 80 days after sowing, with a high potassium solution for all treatments (Table 1). In all cases, the fertigation solutions prepared were applied manually twice a week; until the substrate was saturated.

The experimental design applied was split-plot with completely randomized blocks with eight repetitions and 16 plants per plot. The variables analyzed were collar diameter (CD), total height (TH) and number of leaves per seedling (NL), measured in 120-day-old seedlings. Mycorrhizal colonization percentage was determined in a sample consisting of five seedlings per treatment, using the method of Philips and Hayman (1970); AMF structures were visualized and photographed under a light microscope fitted with a digital camera, making 120 observations per sample, according to McGonigle et al. (1990).

\section{Drought assay}

Fifteen 120 day-old $P$. alba seedlings per treatment from the nursery assay were transferred to the greenhouse at $20-25{ }^{\circ} \mathrm{C}$. Seedlings were acclimated by watering with distilled water twice a week to maintain soil water content close to field capacity during the first 10 days. All containers were allowed to dry until around $10 \%$ of volumetric soil moisture and it was maintained by weighing the container and resupplying the lost water every day for 15 days. At the end of this experiment, 145-day old seedlings were watered to full capacity during 10 days. Survival and resprouting was evaluated by counting the number of plants with new green leaves and shoots (Zeppel et al. 2015). The experimental design was completely randomized.

\section{Statistical analysis}

Mixed linear model was used for the design applied in the nursery using the MIXED procedure; when there were significant differences $(P \leq 0.05)$ between treatments, the comparison of means test was performed using the LSMEANS statement and the ADJUST = TUKEY option in SAS ${ }^{\circledR}$ V.9.1 (SAS Institute Inc.). A generalized model with a binomial family and logit link function was used for the drought assay. Adjusted means were compared a posteriori by the DGC test using INFOSTAT v. 2017.

\section{Results and discussion}

Nursery assay

The addition of fertilization solutions to AMF-inoculated treatments did not promote statistically significant differences $(P=0.4561)$ in mycorrhizal root colonization percentage and was similar for the three AMF inocula, with values between 60 and $70 \%$, suggesting a similar mycorrhizal colonization

Table 2 Mycorrhizal root colonization percentage at different fertilization levels in 120-day-old $P$. alba seedlings from nursery assay

\begin{tabular}{llcr}
\hline Inoculum & \multicolumn{2}{l}{ Fertilization } & \\
\cline { 2 - 4 } & $100 \%$ & $25 \%$ & $0 \%$ \\
\hline PL & 63 & 63 & 65 \\
CB & 69 & 69 & 59 \\
MIX & 59 & 70 & 61 \\
NI & 0 & 0 & 0 \\
\hline
\end{tabular}

PL Padre Lozano, $C B$ Colonia Benítez, $M I X$ mixture of both inocula, NI non inoculated 
capacity of the three inocula (Table 2). In addition, fertilization did not inhibit the formation of the different typical structures of AMF, such as arbuscules, vesicles and hyphae, in the roots of $P$. alba seedlings.

Of all factors affecting the establishment and function of arbuscular mycorrhizal (AM) on plants, fertilizer level is among the most important, however, using fertilizer formulations with less $P$ content allows the formation of them (Linderman and Davis 2004). Yong et al. (2011) suggested that high level of fertilization would reduce the activity of AM symbionts and result in a large loss of AM fungal diversity. Particularly, AMF taxa have been found to be more sensitive than others to specific fertilization conditions. This is probably due to the different taxon-related ability of the AMF taxa to manage nutrient absorption. Among them, Glomeromycota taxa, that are the most aggressive colonists in a high-fertility environment, may be favored directly by fertilization (Liu et al. 2012) and also Glomeraceae species, which are able to cope well with nutrient rich environments (Berruti et al. 2014).

The interaction between inoculum and fertilization was significant in terms of the morphological variables evaluated in the nursery, indicating that the effect of fertilization varies among inocula.

In non-inoculated treatment (NI) growth parameters responded positively to fertilization. The addition of native AMF increased the number of leaves (NL) of non-fertilizer treatments; and PL inoculum also favored increase of collar diameter (CD) and total high (TH) (Fig. 1).

The combined application of AMF and fertilization improved plant behavior with PL inoculum, but not with $\mathrm{CB}$ inoculum or their mixture (Fig. 1). Growth stimulus by AMF was also observed by Bashan et al. (2009), who evaluated three legume species inoculated with $\mathrm{AMF}$, and obtained positive responses for total height, number of branches, and stem thickness. Furthermore, Martin and Stutz (1994) found that inoculation of $P$. alba with Glomus intraradices under optimum production conditions (irrigation and fertilization) modified the root morphology (shorter, thicker and less branched roots) without affecting growth; the authors attributed these results to the role of AMF in substituting for fine feeder roots, which makes $P$. alba allocate more energy resources to increase aerial biomass.

The highest fertilization rate $(100 \%)$ stimulated height growth in seedlings inoculated with PL suggesting that PL fungi favored nutrient assimilation. In addition, the highest number of leaves (NL) was obtained with the PL inoculum under $100 \%$ and $25 \%$ fertilization (Fig. 1). The higher leaf production in inoculated plants suggests that mycorrhizal stimulate ontogeny and delay leaf senescence (Beltrano and Ronco 2008).

Unlike PL, CB inoculum under fertilization (25\% and $100 \%$ ) produced a depressive response to growth compared to non-inoculated plants (NI) (Fig. 1). This response suggests that AMF may become parasitic, since the fungus no longer provides an advantage to the plant under high nutrient levels (Klironomos 2003; Neuhauser and Fargione 2004; Berruti et al. 2014). It has been hypothesized that in a nutrient-rich environment, a plant can directly uptake enough nutrients without the service provided by the AMF partners, causing the decrease in AMF root colonization and
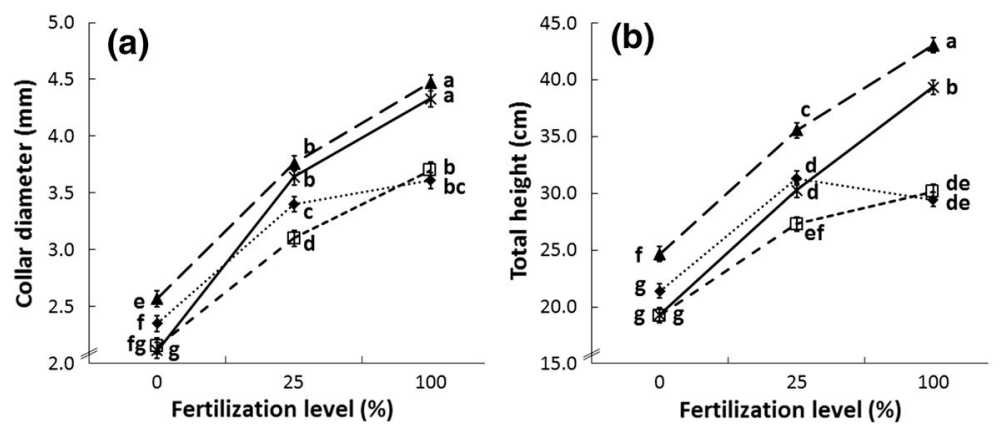

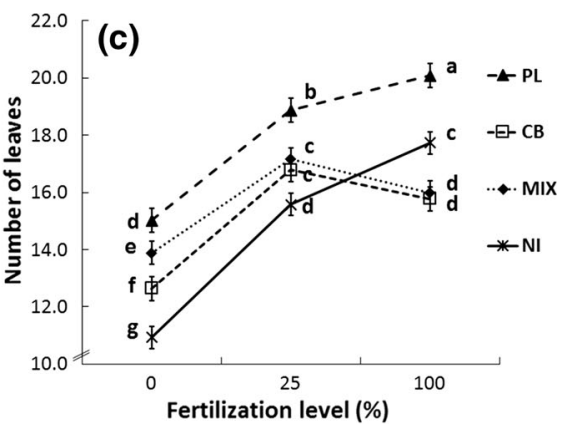

and different letters indicate significant differences between treatments (fertilization $\times$ inoculation $)(P \leq 0.05)$ according to Tukey's test. $P L$ Padre Lozano, $C B$ Colonia Benítez, MIX mixture of both inocula, $N I$ non inoculated 


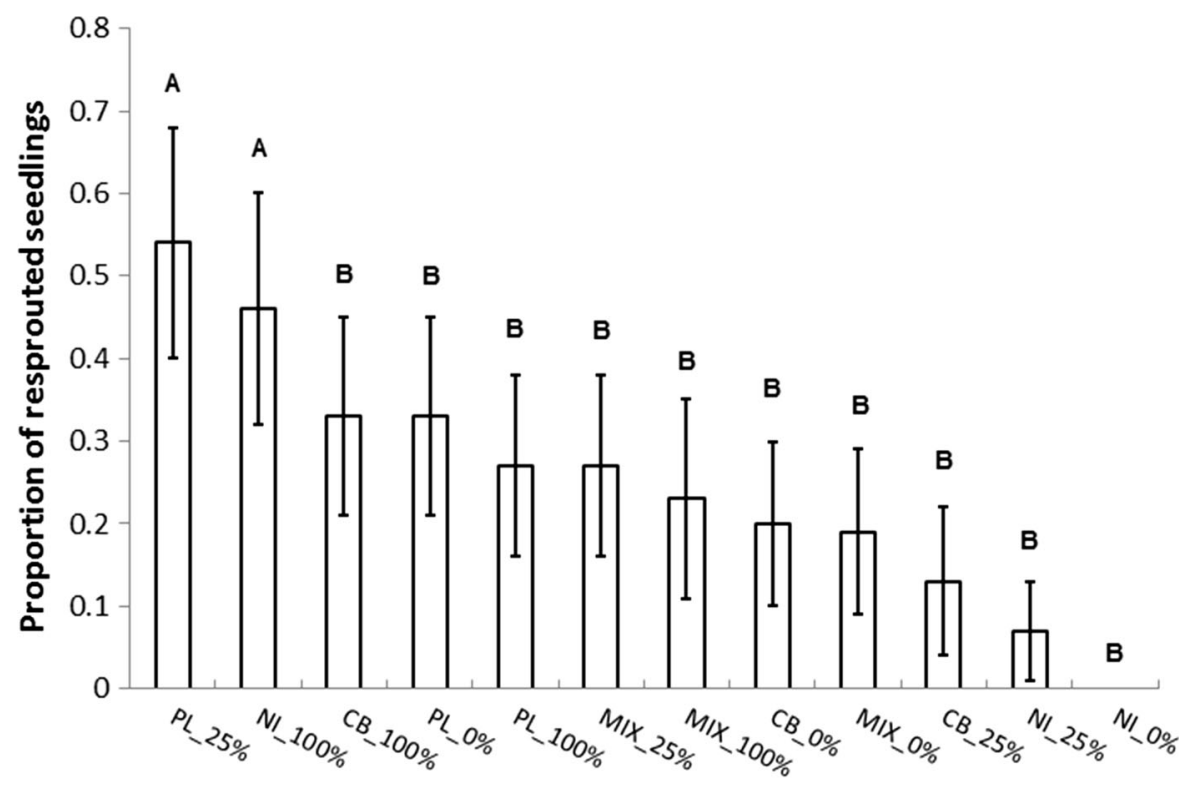

AMF Inoculum x Fertilization

Fig. 2 Effect of drought stress on $P$. alba under different fertilization and AMF inoculation regimes. Resprouting capacity is expressed as the number of resprouted plants after 15 days of drought stress. Vertical bars indicate the standard error of the mean and different letters indicate significant differences

increase fungal competition for limited $\mathrm{C}$ resources (Berruti et al. 2014). The response of the three analyzed variables to the application of the MIX inoculum was at an intermediate position response between the two pure inocula at non-fertilized $(0 \%)$ and $25 \%$ fertilization; however, under $100 \%$ fertilization, responses were similar to that elicited by $\mathrm{CB}$ inoculum (Fig. 1). This result suggests an antagonistic behavior between fungi of both origins, with CB fungi possibly being favored at high fertilization rates. Thus, while some mycorrhizal fungi can be antagonistic to certain pathogens, they can also be antagonistic to other mycorrhizal fungi (Martínez Rojas 2014).

In general, the presence of AMF often significantly affects plant growth; however, the direction and magnitude of this effect depends on the particular fungus-plant species combination, and on their source (native or exotic) (Klironomos 2003). Our results from the nursery assay revealed that inoculation with mixed AMF from PL, a region characterized by low rainfalls (650 mm), improved $P$. alba seedling growth significantly compared to $\mathrm{CB}(1300 \mathrm{~mm})$ inoculum and their combination and this effect was stimulated by mineral fertilization. The highest number of leaves between treatments (fertilization $\times$ inoculation) $(P \leq 0.05)$ according to DGC's test. Treatments are combination of inoculation ( $P L$ Padre Lozano, $C B$ Colonia Benítez, $M I X$ mixture of both inocula, NI non inoculated) and fertilization levels $(0 \%, 25 \%, 100 \%)$

with the PL inoculum under $100 \%$ and $25 \%$ fertilization (Fig. 1) support this statement. This is consistent with observations reported by Cruz Hernández et al. (2014) in seedlings of Nicotiana glauca. They showed that when applying $75 \%$ of mineral fertilizer + Glomus cubense it was possible to obtain a production with the same yield and quality that when applying $100 \%$ of mineral fertilizer. Many studies have shown that AMF are not able to fully replace fertilization; however, they can improve mineral nutrient uptake (Adesemoye and Kloepper 2009).

\section{Drought stress assay}

In our study, $P$. alba resprouting capacity, after drought stress conditions, varied with the different inocula and fertilization levels. The non-inoculated and non-fertilized treatment exhibited the lowest resprouting index of all treatments. By contrast, the effect of the AMF inocula $\times$ fertilization was significant $(P=0.0198)$, and a posteriori comparisons indicate that the proportion of resprouted plants in the treatments corresponding to non-fertilizer PL (PL_0\%) and PL under fertilization 25\% (PL_25\%) 
were significantly higher than in the rest of the treatments, among which no statistically significant differences were observed (Fig. 2). Thus, our results demonstrated that an AMF inoculum isolated from the driest regions of the study area, such as PL, would have the potential for mitigating drought stress in $P$. alba seedlings compared to inoculum isolated from less dry areas. These results agree with observations reported by Ruiz-Lozano et al. (1995), Klironomos (2003) and Marulanda et al. (2006), who found that differences between AMF in efficiency to increase drought tolerance and plant growth depended on the AMF origin.

On the other hand, Al-Karaki et al. (2004) indicate that it may also be necessary to select AMF adapted to the environment in which a plant species is to be grown. In the present study, spores of AMF from PL and CB morpho-taxonomically identified by Sagadin et al. (2018) were used. Both inocula had Claroideoglomus etunicatum, commonly found in degraded environments (Irrazabal et al. 2005), being very efficient when plants are exposed to high stress conditions (Ruiz-Lozano et al. 1995). Also, both PL and CB inocula showed Funneliformis mosseae which has been shown sensitive only to high grazing pressures ( $\mathrm{Su}$ and Guo 2007) and Rhizophagus intraradices, which has greater tolerance to environmental stress and grazing (Yang et al. 2013). Only PL inocula showed Diversispora spurca, an AMF tolerant to drought stress conditions (Ruiz-Lozano et al. 1995) and Claroideoglomus claroideum, mentioned by Marulanda et al. (2003) as an AMF with greater capacity to deplete soil water content under drought stress condition.

In containerized seedling production, a reduced space for roots and substrate limits water and nutrients availability, therefore watering and fertilization regimes need to be fine-tuned to avoid waste and water courses pollution. Our results highlight the role of AMF in making a more resource-efficient and high quality seedling production, avoiding high input fertilization regimes and enhancing their survival under water stress.

\section{Conclusions}

During seedling production in containers, a fertilization scheme is necessary to promote seedling growth.
Our results showed that the combined application of native AMF and fertilization did not affect mycorrhizal colonization and allowed the formation of the different AMF structures. The PL inoculum, originated in regions of low rainfall, enhanced growth under nursery and drought tolerance under greenhouse conditions, suggesting that its greater capacity for benefiting $P$. alba is related to environmental conditions of the site of inoculum origin. Moreover, AMF inoculation with low fertilization rates showed a synergistic effect on growth. AMF are a promising microbiological tool for the sustainable commercial production of $P$. alba seedlings; therefore, we propose including inoculation with AMF in seedling production systems.

Acknowledgements This work was supported by National Institute of Agricultural Technology (INTA): PReT-ERIOS 1263305, INTA-PNFOR 1104073, INTA-PNFOR 1104063 and INTA-PNAGUA 1133032; National Promotion Agency Science and Technology (ANPCyT) through the Fund for Scientific Research and Technology (FONCyT): Projects of Scientific and Technological Research (PICT) 2012-0339. We also like to thanks to Jorgelina Brasca for manuscript language editing, Ing. Ingrid Teich for her contributions to statistical analysis of drought data and all the technical staff who helped with the establishment and maintenance of the nursery test.

\section{Compliance with ethical standards}

Conflict of interest The authors declare that they have no conflict of interest.

\section{References}

Adesemoye AO, Kloepper JW (2009) Plant-microbes interactions in enhanced fertilizer-use efficiency. Appl Microbiol Biotechnol 85:1-12. https://doi.org/10.1007/s00253-0092196-0

Al-Karaki G, McMichael B, Zak J (2004) Field response of wheat to arbuscular mycorrhizal fungi and drought stress. Mycorrhiza 14(4):263-269. https://doi.org/10.1007/ s00572-003-0265-2

Asmelash F, Bekele T, Birhane E (2016) The potential role of arbuscular mycorrhizal fungi in the restoration of degraded lands. Front Microbiol 7:1095. https://doi.org/10.3389/ fmicb.2016.01095

Bashan Y, Salazar B, Puente ME (2009) Responses of native legume desert trees used for reforestation in the sonoran desert to plant growth-promoting microorganisms in screen house. Biol Fertil Soils 45:655-662. https://doi.org/10. 1007/s00374-009-0368-9

Beltrano J, Ronco MG (2008) Improved tolerance of wheat plants (Triticum aestivum L.) to drought stress and rewatering by the arbuscular mycorrhizal fungus Glomus 
clroideum: effect on growth and cell membrane stability. Braz J Plant Physiol 20(1):29-37. https://doi.org/10.1590/ S1677-04202008000100004

Berruti A, Borriello R, Orgiazzi A, Barbera AC, Lumini E, Bianciotto V (2014) Arbuscular mycorrhizal fungi and their value for ecosystem management. In: Grillo O (ed) Biodiversity - the dynamic balance of the planet. In Tech, pp 159-191. https://www.intechopen.com/books/ biodiversity-the-dynamic-balance-of-the-planet/ arbuscular-mycorrhizal-fungi-and-their-value-forecosystem-management. Accessed 08 Feb 2018

Biermann B, Linderman RG (1983) Effect of container plant growth medium and fertilizer phosphorus on establishment and host growth response to vesicular-arbuscular mycorrhizal. J Am Soc Hort Sci 108(6):962-971

Cabello MN (1997) Hydrocarbon pollution: its effect on native arbuscular mycorrhizal fungi (AMF). FEMS Microbiol Ecol 22(3):233-236

Cruz Hernández Y, Garcia Rubido M, León González Y, Acosta Aguiar Y (2014) Influencia de la aplicación de micorrizas arbusculares y la reducción del fertilizante mineral en plántulas de tabaco. Cultivos Tropicales 35(1):21-24

Irrazabal G, Schalamuk S, Velázquez MS, Cabello M (2005) Especies de hongos formadores de micorrizas arbusculares: nuevas citas para la República Argentina. Bol Soc Argent Bot 40(1-2):17-22

Jacobs DF, Landis TD (2009) Fertilization. In: Dumroese RK, Luna T, Landis TD (eds) Nursery manual for native plants: a guide for tribal nurseries, volume 1: nursery management. Agriculture Handbook 730, Department of Agriculture, Forest Service, Washington, pp 201-215

Klironomos JN (2003) Variation in plant response to native and exotic arbuscular mycorrhizal fungi. Ecology 84(9):2292-2301. https://doi.org/10.1890/02-0413

Linderman RG, Davis EA (2004) Evaluation of commercial inorganic and organic fertilizer effects on arbuscular mycorrhizae formed by Glomus intraradices. HortTechnol 14(2):196-202

Liu Y, Shi G, Mao L, Cheng G, Jiang S, Ma X, An L, Du G, Johnson NC, Feng H (2012) Direct and indirect influences of $8 \mathrm{yr}$ of nitrogen and phosphorus fertilization on Glomeromycota in an alpine meadow ecosystem. New Phytol 194:523-535. https://doi.org/10.1111/j.1469-8137.2012. 04050.x

Martin CA, Stutz JC (1994) Growth of argentine mesquite inoculated with vesicular-arbuscular mycorrhizal fungi. J Arboric 20(2):134-139

Martínez Rojas L (2014) Respuesta del cultivo de pimentón (Capsicum annuum) a la inoculación con Glomus manihotis y Acaulospora lacunosa en suelo con niveles alto de fosforo. Respuestas 19(1):27-38. https://doi.org/10.22463/ 0122820X.6

Marulanda A, Azcón R, Ruiz-Lozano JM (2003) Contribution of six arbuscular mycorrhizal fungal isolates to water uptake by Lactuca sativa plants under drought stress. Physiol Plant 119(4):526-533. https://doi.org/10.1046/j.1399-3054. 2003.00196.x

Marulanda A, Barea JM, Azcón R (2006) An indigenous drought-tolerant strain of Glomus intraradices associated with native bacterium improves water transport and root development in Retama sphaerocarpa. Microb Ecol 52:670-678. https://doi.org/10.1007/s00248-006-9078-0

McGonigle TP, Miller MH, Evans DG, Fairchild GL, Swan JA (1990) A new methods which gives an objective measure of colonization of roots by vesicular-arbuscular mycorrhizal fungi. New Phytol 115:495-501. https://doi.org/10. 1111/j.1469-8137.1990.tb00476.x

Neuhauser C, Fargione JE (2004) A mutualism-parasitism continuum model and its application toplant-mycorrhizae interactions. Ecol Model 177:337-352. https://doi.org/10. 1016/j.ecolmodel.2004.02.010

Pausas JG, Pratt RB, Keeley JE, Jacobsen AL, Ramirez AR, Vilagrosa A, Paula S, Kaneakua-Pia IN, Davis SD (2016) Towards understanding resprouting at the global scale. New Phytol 209:945-954. https://doi.org/10.1111/nph. 13644

Philips J, Hayman D (1970) Improved procedures for clearing roots and staining parasitic and vesicular-arbuscular mycorrhizal fungi for rapid assessment of infection. Trans $\mathrm{Br}$ Mycol Soc 55:158-161. https://doi.org/10.1016/S00071536(70)80110-3

Rapparini F, Peñuelas J (2014) Mycorrhizal fungi to alleviate drought stress on plant growth. In: Miransari M (ed) Use of microbes for the alleviation of soil stresses, vol 1. Springer, New York, pp 21-42

Ruiz-Lozano JM, Azcón R, Gomez M (1995) Effects of arbucular-mycorrhizal Glomus species on drought tolerance: physiological and nutritional plant responses. J Appl Environ Microbiol 61(2):456-460

Sagadin MB, Monteoliva MI, Luna CM, Cabello MN (2018) Diversidad e infectividad de hongos micorrícicos arbusculares nativos provenientes de algarrobales del Parque Chaqueño argentino con caracteríticas edafoclimáticas contrastantes. Agriscientia 35(2):19-33

Salifu KF, Jacobs DF (2006) Characterizing fertility targets and multi-element interactions in nursery culture of Quercus rubra seedlings. Ann For Sci 63:231-237. https://doi.org/ 10.1051/forest:2006001

Salto CS, Harrand L, Oberschelp GPJ, Ewens M (2016) Crecimiento de plantines de Prosopis alba en diferentes sustratos, contenedores y condiciones de vivero. Bosque. https://doi.org/10.4067/S0717-92002016000300010

Salto CS, Melchiorre M, Oberschelp GPJ, Pozzi E, Harrand L (2017) Effect of fertilization and inoculation with native rhizobial strains on growth of Prosopis alba seedlings under nursery conditions. Agrofor Syst. https://doi.org/10. 1007/s10457-017-0156-8

Sieverding E (1991) Vesicular arbuscular mycorrhizae management in tropical agroecosystem. Technical Cooperation, Federal Republic of Germany

Su YY, Guo LD (2007) Arbuscular mycorrhizal fungi in nongrazed, restored and over-grazed grassland in the Inner Mongolia steppe. Mycorrhiza 17:689-693. https://doi.org/ 10.1007/s00572-007-0151-4

Velazquez S, Cabello M (2011) Occurrence and diversity of arbuscular mycorrhizal fungi en trap cultures from El Palmar National Park soils. Eur J Soil Biol 47(4):230-235

Villagra PE, Vilela A, Giordano C, Alvarez JA (2010) Ecophysiology of Prosopis species from the arid lands of Argentina: What do we know about adaptation to stressful 
environments? In: Ramawat KG (ed) Desert plants: biology and biotechnology. Springer, London, pp 321-340

Wilkinson KM (2009) Benefical microorganisms. In: Dumroese RK, Luna T, Landis TD (eds) Nursery manual for native plants: a guide for tribal nurseries, volume 1: nursery management. Agriculture Handbook 730, Department of Agriculture, Forest Service, Washington, pp 247-261

Yang W, Zheng Y, Gao C, He X, Ding Q, Kim Y, Rui R, Wang S, Guo L (2013) The arbuscular mycorrhizal fungal community response to warming and grazing differs between soil and roots on the Qinghai-Tibetan Plateau. PLoS ONE 8(9):e76447.

https://doi.org/10.1371/journal.pone. 0076447
Yong LJ, Shi GX, Mao L, Cheng G, Jiang SF, Feng HY (2011) Effects of fertilization on arbuscular mycorrhizal fungi in Elymus nutans roots. Chin J Appl Ecol 22(12):3131-3137

Zeppel MJB, Harrison SP, Adams HD, Kelley DI, Li G, Tissue DT, Dawson TE, Fensham R, Medlyn BE, Palmer A, West AG, McDowell NG (2015) Drought and resprouting plants. New Phytol 206:583-589

Publisher's Note Springer Nature remains neutral with regard to jurisdictional claims in published maps and institutional affiliations. 